\title{
Introducing the Vector: How coconut lethal yellowing disease may have reached the Caribbean.
}

\author{
Laura Ogle and Hugh Harries
}

\begin{abstract}
Recent reports from Jamaica tell of an increase in the incidence of coconut lethal yellowing disease and raise the spectre of the epidemic of forty years ago. Is this just another coincidence in a series that seem to link the disease with Jamaica? The future threat is to susceptible coconut varieties in Caribbean islands from Puerto Rico to Trinidad and Latin American countries from Nicaragua to Brazil. Will the disease progress in domino fashion from country to country or will it jump some countries to reach others? To answer this, consider the possibility that the disease originated outside the Caribbean and if it did, how did it first reach Jamaica?
\end{abstract}

Coconut lethal yellowing is a phytoplasma disease and, in the absence of any contrary evidence, plant pathologists believe that phytoplasma diseases are NOT carried from place to place by seeds. Rather, they ARE transmitted from plant to plant by insect vectors. So the first coconuts, taken to Jamaica in the 16th century would not have carried the disease. Since the palms became widespread through the island over the following three centuries (Harries 1980), it is unlikely that the disease was already present during that time. The same can be said everywhere else in Latin American and the Caribbean where all coconuts share a similar history of introduction and healthy establishment (Harries 2001).

So it is unfortunate that some popular and scientific accounts of coconut lethal yellowing disease imply that "it originated in Jamaica" or that "it reached continental USA and Mexico from Jamaica". The same disease occurs in Hispaniola (Haiti \& Dominican Republic), the Bahamas (reputedly) and the Cayman Islands, as well as in Cuba. Cuba, by its greater size and proximity to the continent, might seem a more likely focus for the disease. What these accounts are indirectly acknowledging is that it was the publicity generated by a successful Research and Development program during the 1960s and 70s (Gowdie \&
Romney 1976) that has held Jamaica in the lethal yellowing spotlight.

The disease has spread throughout Jamaica and Cuba, to a lesser extent in Haiti (but, exceptionally, not at all in Dominican Republic (Harries et al. 2001)), the Gulf Coast states of USA and Mexico and the Caribbean coast from Mexico to Honduras (Harries 2001). Before the disease inexorably moves to other Latin American countries, from Nicaragua to Brazil, and Caribbean islands, from Puerto Rico to Trinidad and Tobago, there may be more to be learned from Jamaica where, even now, disease activity seems to be reintensifying.

\section{Incidence and Coincidence}

Over the years, many plants have been introduced to Jamaica, ranging from those that became important crops like banana, cocoa, coconut, citrus, coffee and sugar cane to innumerable decorative garden plants, such as violets or roses (Webster 1968). By 1687, coconut palms were common, and presumably healthy (Sloane 1696).

\section{Correspondence}

Laura Ogle, International Centre for Environmental and Nuclear Sciences (ICENS), University of the West Indies, Mona Campus, Kingston 7, JAMAICA.

logle@mail.infochan.com

Hugh Harries, Royal Botanic Gardens, Kew, Richmond, Surrey TW9 3AE, UNITED KINGDOM.

H.Harries@rbgkew.org.uk

Ethnobotany Research \& Applications 3:139-142 (2005) 
About 1782 Admiral Rodney presented Hinton East (the Receiver General whose private garden at Ligunea became Hope Botanic Garden) with plants from the Celebes (Suluwesi, Indonesia) including Pandanus (Webster 1968) (now considered to be a host to phytoplasma disease in Florida (Thomas \& Donselman 1979)). In 1793, Captain Bligh brought hundreds of breadfruit plants and just four coconut seedlings from Tahiti (Powell 1973). In fact both Rodney and Bligh, like other naval and mercantile sea captains, would always have carried coconuts whenever they sailed in tropical waters. The coconut, was a source of drinking water and an important shipboard item but - like the ship's cat which was needed to control rats and mice on board - the coconuts would not have been remarkable (and like the ship's cat their progeny could be found at every port of call). There is presently no indication that any introduced coconuts carried the lethal yellowing phytoplasma and therefore every reason to believe that the disease reached the island by some other means.

The possibility that cattle may have been involved may seem improbable until it is remembered that when cattle are transported by boats they require considerable quantities of food (Plimsoll 1890). Although cattle food might generally be taken on board ship in the form of dried hay and grains, it is also likely that fresh vegetation was carried for animals in the 19th century, before strict plant quarantine regulations were in force. That fodder could have been carrying infected insect vectors, or it may itself have been a secondary host to the phytoplasma. Is there any evidence for either of these ideas?

Livestock was certainly carried to Jamaica by the earliest settlers (Lecky 1996) but European animals would not have had any connection with tropical plant diseases. In contrast, Zebu cattle were imported from India (via Portugal) in 1850 and went to Shettlewood and Montpelier area of St James (Lecky 1996). This is the western end of the island virtually midway between the parish of St Elizabeth where yellowing coconut palms were reported by the Marquis of Sligo in 1872 and Montego Bay where the first reported coconut disease (Fawcett 1891) was subsequently named "West End bud rot". More cattle were imported to Jamaica from India: five Mysores in 1880; four Guzarat in 1885, followed by Gir and Hassar cattle; and, as late as 1920, two Sahiwal bulls (Lecky 1996). The incidence of coconut disease in Jamaica and the movement of cattle from India is the first coincidence in the association of lethal yellowing disease with Jamaica. Because there is also a long-term coconut disease in India (Butler 1908), now called "root (wilt) disease" that dates back to 1882 and is (arguably) associated with phytoplasma (Koshy 1999).

By 1910 the army had imported Seymour grass (Andropogon [Bothriochloa] pertusus to Jamaica from India (Lecky 1996), probably for horses and mules rather than for cattle but with the same element of risk. The danger is not necessarily from phytoplasma infected plants, because these would have been relatively few in number, presumably unhealthy, and would have had limited distribution after arrival. By contrast, populations of infected insect vectors that can live on fresh pasture planting material would have survived the voyage and found ideal conditions to multiply and spread quickly after arrival. A related grass, Foxtail, (Andropogon bicornis) has been identified as a host to the lethal yellowing vector, the planthopper Myndus crudus (Howard 1990). Pasture grasses accompanying cattle coming to Jamaica from India might have carried some of the numerous sap-sucking insects recorded from coconuts and other palms in India (Nair \& Babu 2001) that are also known to occur in Jamaica (Eskafi 1982).

Another fodder plant that arouses even more interesting suspicions is Uba cane (Saccharum sinense). The name given to this relative to sugar cane in Jamaica was apparently due to some of the letters on a label marked "DURBAN" having become illegible on the water-soaked package containing the cane setts sent from Natal to Jamaica during the First World War (Lecky 1996). Although only scattered coconuts grow on the border between Natal (KwaZulu-Natal) and Mozambique the lethal disease that occurs in Mozambique was suspected (but never proved) from Natal (Anon 1989); the reputed LY vector Myndus crudus is sometimes known as the "yellow sugarcane leafhopper" (pers. comm to Pieter Cronje from Nigel Harrison) and sugar cane (Sacharum officianale) is also a host for a phytoplasma disease (apparent differences between phytoplasmas are not based on pathogenicity).

But what if the label on the cane setts had said Cuba? It has recently come to light that coconuts in Cuba had been ravaged by "a disease known in the western department since 1870, it having appeared at Matanzas" (Ramsden 1890). The disease was very active in that country from 1905 onwards. It was subsequently reported that export production from Baracoa in 1905 was 17,113,572 coconuts and that by 1910 that quantity had decreased to $6,177,170$ (Bruner \& Boucle 1943). A 64\% reduction in 5 years is greater than the epidemic that occurred in Jamaica 60 years later. Cuba, like Jamaica, might also have imported tropical cattle and tropical fodder crops from other coconut growing countries. Jamaica would not have been the only Caribbean country where cattle and fodder plants were introduced in the 19th century - it simply has a better set of records for that period. Cattle and cattle fodder might also have been taken to West African countries such as Cameroon, Togo or Ghana which have a similar history of a phytoplasma disease destroying coconuts three hundred years after their 16th century introduction (Harries 1991; 1997). 


\section{Discussion}

How or when lethal yellowing disease arrived in Jamaica, either as an infected plant of some, as yet, unidentified but otherwise desirable alternate host, or, as this paper suggests, by the unintentional introduction of infected vectors on pasture grasses or animal fodder, is of more than academic interest. It suggests the following lines of research:

1. Identification of LY vectors by radioactive tracing of phytoplasma infected insects, as a follow up of neglected earlier original work (Eskafi 1982) with the benefits of modern PCR techniques and taking advantage of the availability of a source of nuclear material and skilled, experienced personnel at UWI Jamaica. When Eskafi injected radioactive materials into coconut palms and then identified insects that had fed from those palms he experienced many problems and delays because the techniques were novel in Jamaica at that time and various permissions were required. The work was planned as early as 1977 but not carried out until 1979 and was published in late 1982. By that time the impetus of research in Jamaica and Florida was over and the findings and recommendations made by Eskafi were never followed up.

2. Similar radioactive tracer experiments on vector host grasses would be possible, and may identify secondary hosts for the LY phytoplasma.

3. Experimental control of vector or pathogen by irradiation of plant material. Although the coconut seednut is not known to have been responsible for the transmission of lethal yellowing phytoplasma or its vector, the danger has always been apparent and in recent years there was an embargo on the shipment of dry coconuts from the Dominican Republic to Brazil. This situation was only eased when it was shown that lethal yellowing had never become epidemic in Dominican Republic because it had never reached the main coconut growing area which could therefore be considered as a pest free area (Harries et al. 2001). The risk of vector transfer into areas of healthy coconuts might be reduced if irradiation treatments could be shown to control the vector (and the pathogen) without harm to the coconut (and other plants) or risk to the environment.

4. Reduction of natural vector population by sterile-male release methods. More needs to be known about the vector of lethal yellowing. In fact there may be more than one insect vector. Sterilization of males and their release might be a possible means of delaying or stopping the entry of lethal yellowing into new areas and would be particularly applicable to Caribbean islands where the necessary isolation may be achieved more readily.

\section{Acknowledgements}

The authors publish with permission of their respective institutions but the opinions expressed do not necessarily represent the views of ICENS or RBG, Kew. They are particularly grateful to members of the CICLY discussion group http://groups.yahoo.com/group/cicly for free and open exchange of information and ideas.

\section{Literature Cited}

Anonymous. 1989. Natal beware. The Palm Enthusiast [Journal of the South African Palm Society] 6(2):23.

Bruner S.C \& L. Boucle. 1943. La Enfermedad conocida por "Pudricion del Cogollo de Cocotero en Cuba". Revista de Agricultura (L'Habana) 26:132-141.

Butler, E.J. 1908. Report on coconut palm disease in Travancore. Agricultural Research Institute Pusa 9: 1-23.

Eskafi, F.M. 1982. Leafhoppers and planthoppers feeding on coconut palm in Jamaica. Tropical Agriculture (Trinidad) 59:289-292.

Fawcett, W. 1891. Report on the coconut disease at Montego Bay. Bulletin of the Botanical Department (Jamaica) 23:2.

Gowdie, A.L. \& D.H. Romney. 1976. Replanting coconuts in Jamaica through the lethal yellowing insurance regulations. Agricultural Administration 3:125-131.

Harries, H.C. 1980. The Natural History of the Coconut (in Jamaica). Jamaica Journal 44:60-66.

Harries, H.C. 1991. The vulnerability of the coconut genetic resources of Africa. First Burotrop Meeting, Arusha, Tanzania, February 1991.

Harries, H.C. 1997. Growing coconut in Africa: resistance to lethal yellowing-like diseases. International Workshop on Lethal Yellowing-like Diseases of Coconut. Elmina, Cape Coast, Ghana 5-10 November 1995.

Harries, H.C. 2001. Coconut varieties and lethal yellowing: a regional perspective for the Americas. Palms 45:148-150.

Harries, H.C., C.J. Herasme \& E. Hichez Frías. 2001. Why lethal yellowing has not become epidemic in the Dominican Republic. Palms 45:92-96.

Howard, F.W. 1990. Evaluation of grasses for cultural control of Myndus crudus, a vector of lethal yellowing of palms. Entomologia Experimentalis et Applicata 56:131137. 
Koshy, P.K. 1999. Root (wilt) disease of coconut. Indian Phytopathology 52:335-353.

Lecky, T.P. 1996. Cattle and I: An autobiography. Ian Randle Publishers, Kingston.

Nair, R.K \& M.K. Labu. 2001. Sap-sucking insects of oil palm (Elaeis guineensis Jacq.) and their occurrence on coconut (Cocos nucifera L.), arecanut (Areca catechu L.) and Elaeis oleifera in Kerala State, India. The Planter 77:21-20.

Plimsoll, S. 1890. Cattle Ships. Kegan Paul, London.

Powell, D. 1973. The voyage of the plant nursery, HMS Providence, 1791-1793. Bulletin - Institute of Jamaica, Science Series No. 15, Part 2.

Ramsden, F. 1890. Cocoanuts, and diseases of the trees. Letter from the Consul for St Jago de Cuba (Spain), Francis Ramsden to the Marquis of Salisbury dated July 7, 1890, published in the Diplomatic and Consular Reports on Trade \& Finance for 1890, Volume IV, Number 779:1112.

Sloane, H. 1696. Catalogus plantarum quae in insula Jamaica sponte proveniunt. Brown, London.

Thomas, D.L. \& H.M. Donselman. 1979. Mycoplasmalike bodies and phloem degeneration associated with declining Pandanus in Florida. Plant Disease Reporter 63:911916.

Webster, A. 1968. Caribbean Gardening. Spottiswoode, Ballantyne, London. 